\title{
Construction and Experience of Automobile Marketing Curriculum group
}

\author{
Jun-Tao XIAO \\ School of economic and management \\ Hubei University of Automotive Technology \\ Shiyan-City, China \\ 1931557404@qq.com
}

\author{
En-De ZHOU \\ School of economic and management \\ Hubei University of Automotive Technology \\ Shiyan-City, China \\ 360301381@qq.com
}

\begin{abstract}
For colleges and universities, it is necessary to cultivate high-level and applied talents of automobile marketing through building automobile marketing curriculum group. The automobile marketing course group consists of theoretical course group and practice training. The theoretical curriculum is composed of the core course of automobile marketing and a number of related courses. Practice training is composed of automobile disassembling practice, auto show exercitation, auto market research, automobile marketing plan, automobile marketing virtual simulation training and automobile marketing internship. The construction and experience of automobile marketing curriculum group create talent training modes and improve integrating degree between cultivating talents and social development needs.
\end{abstract}

Keywords-curriculum group;automobile marketing;talent cultivation; construction and experience insert

\section{INTRODUCTION}

With the rapid development of automobile industry in China, the demand for automobile talents is also increased dramatically. According to incomplete statistics, the gap of automotive talent will reach 300000 people in the next 10 years especially the demand of high-level automobile marketing talents is most needed. So it adapts to the needs of society to cultivate high-level automobile marketing talents through the construction of auto marketing curriculum group. It also has effectively support the promotion of talent training quality and achieves the goals of talents cultivation.

\section{THE CONNOTATION AND CHARACTERISTICS OF CURRICULUM GROUP}

The concept of curriculum group is firstly proposed by $\mathrm{Mr}$. Jia-cai Wang of Beijing institute of technology in China. There are six kinds of state generalized by Mr. Chang-pu Ma about the connotation of the curriculum group [1]. Firstly, it is the organic integration of integrated course which can constitute independent complete system of the teaching content of related courses in planning and guided by the modern education thought. Secondly, curriculum group is interdependent and scientific course groups which is comprised by more than three related or similar structure courses. One of them is basal. Thirdly, the curriculum group is refers to the number of independent and closely linked each other courses. Fourthly, the curriculum group is an organic whole that is constituted with several series of corresponding courses. They are equipped with corresponding teaching resources, and construct the lessons according to the curriculum framework, so can obtain the overall superiority and makes the discipline advantage. Fifthly, the curriculum group is the group refers to the course belong to a subject. It has a reasonable division of labor between each other and can meet different teaching requirement of different majors. Sixthly, curriculum group is to perfect the courses system composed of some course. The courses maybe belong to different discipline and exit logic relation. The main purpose of curriculum group is improving the knowledge structure of teaching object [2].

In my opinion, the curriculum group refers to certain logic connection of course groups with one specific knowledge and ability cultivation as the theme according to social needs and personnel training target. Group has the following features: One is the curriculum group serve talent cultivation, and usually belongs to a major or a discipline. Two is the course of curriculum group is associated which usually around a theme and has a certain logic connection. Three is although the curriculum group mainly relying on a professional, it can be strutted cross-discipline and be served more than one professional.

\section{The Research Status OF The CURRICUlum GROUP}

In recent years, many scholars studied the curriculum group. Some scholars put forward the concept of professional course group and have studied the curriculum group of electronic business professional, marketing major, mechanical design major, Automation major, the computer professional, information management professional and so on[3]. Some scholars have discussed the he difference and contact between courses, curriculum group and curriculum system [4]. Even some scholars think that the construction and reform of curriculum group is a new development trend on higher education. It can promote the integration of professional courses and optimizing the allocation of various teaching resources [5]. We can draw such a conclusion that the current study of curriculum group of practice mainly in two aspects from above research, one is the study of professional course group construction. Another is the construction of curriculum group around one core course. The curriculum group of automobile marketing is based on the core course of 
automobile marketing. So far, there is no research about construction of automobile marketing course group.

\section{The NeCESSity ON THE CONSTRUCTION OF AUTOMOBILE MARKETING CURRICULUM GROUP}

We should meet the needs of national and regional economic and social development, constantly optimize the structure of higher education, focus on expanding applied, compound, skilled personnel training scale according to "The national medium and long-term education reform and development plan outline (2010-2020)". Automobile marketing is the bond connected automobile manufacturing and services and is the inevitable result of the automobile manufacturing. It also combines the important connotation of auto service. Auto marketing talent is applied, compound and skilled talents. Several years ago, automobile marketing talents mainly come from the business management and marketing professional. However, with the increase of demand for high-level automobile marketing talents, the source of automobile marketing talent expanded multiple professional fields, such as the vehicle engineering profession, automobile service engineering profession, e-commerce profession, international economy and trade profession, and so on. Traditional course of automobile marketing has far cannot satisfy the needs of automobile industry. It is very necessary that building course group of automobile marketing, make automobile marketing talent have comprehensive knowledge, ability and quality and suitable for more professional.

\section{Construction of Automobile Marketing CURRICULUM GROUP}

The curriculum group of Automobile marketing was constructed by Hubei University of Automotive Technology. The curriculum group is leaded by national and provincial excellent courses, supported by series of characteristic teaching materials, as the means of industry-education integration, and has outstanding characteristic.

\section{A. Construction Idea of Automobile Marketing Curriculum Group}

Firstly, we know how knowledge system to cultivate automobile marketing talent through the research on automotive industry. Secondly, auto marketing talent training scheme was formed combined research with high-level applied talents cultivation orientation. Thirdly, the curriculum group of automobile marketing was built according to auto marketing talent training scheme. Fourthly, the causes of curriculum group gradually achieve quality and network. The construction idea above was shown in Fig. 1.

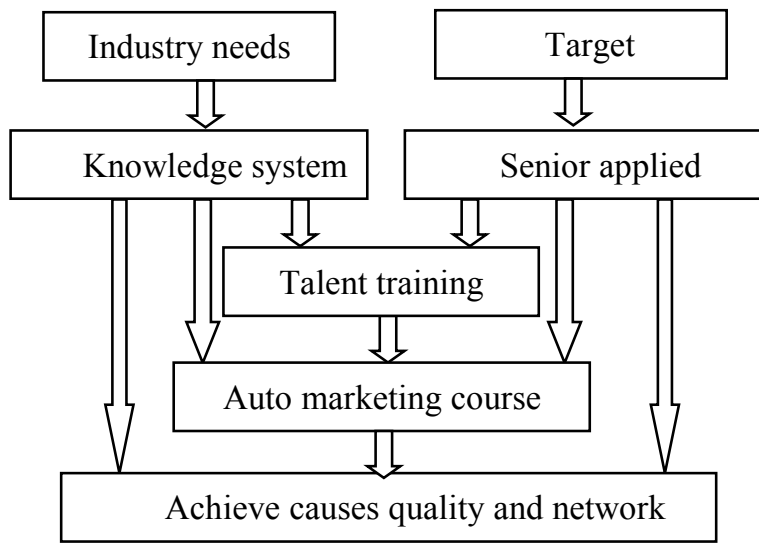

Fig. 1. Construction idea of automobile marketing clause group

\section{B. The Framework of Automobile Marketing Curriculum Group}

The curriculum group of automobile marketing is consists of the following characteristic courses: automobile marketing, automobile structure, automobile culture, automobile parts marketing, automobile finance, automobile insurance and claims, automobile sales practice, used-car trade, automobile marketing lectures, etc. As shown in the Fig. 2. Curriculum group provides effective support for cultivating high quality automobile marketing talent.

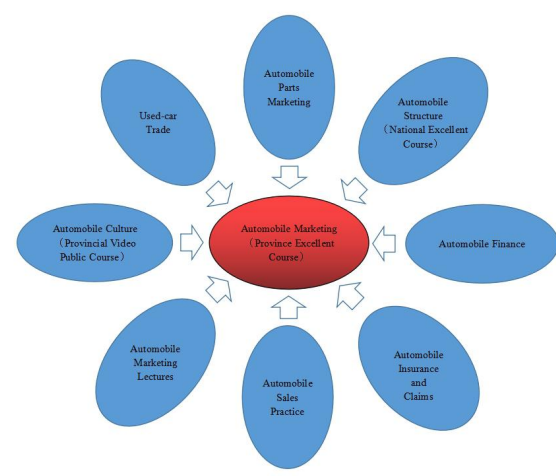

Fig. 2. The framework of automobile marketing curriculum group

The courses of automobile marketing curriculum group are not isolated. They formed the organic unity of the whole according to the need of automobile marketing knowledge, ability and skills. Specific as follows: understanding automotive structure knowledge corresponding to the course of "automobile structure", master the knowledge of automobile marketing and automobile parts marketing respectively corresponding to the course of "automobile marketing" and "automobile parts marketing", mastering sales skills and practice corresponding to the course of "automobile sales practice", mastering the knowledge of auto finance and car insurance respectively corresponding to the course of "automobile finance" and "automobile insurance and claims", grasping of the knowledge of second-hand car marketing corresponding to the course of "used-car trade", knowing auto cultural knowledge corresponding to the course of " automobile culture", comprehending frontier knowledge of automobile marketing corresponding to the course of 
"automobile marketing lectures". In the process of teaching, teachers pay attention to avoid content repetition between the courses of group, improve teaching efficiency and reduce the burden of the students, effectively make students master relevant knowledge and ability of automobile marketing. Currently, curriculum group team has built a national excellent course that is "automobile structure", a province excellent course that is "automobile marketing", and a provincial video public course that is "automobile culture".

\section{The Practice Training Framework of Automobile Marketing Curriculum Group}

The Automobile marketing curriculum group need practice training to support because the cultivation of automobile marketing talent requires high practice ability. Its practice training successively is automobile disassembling practice, auto show exercitation, auto market research, automobile marketing plan, automobile marketing virtual simulation training and automobile marketing internship. As shown in the Fig. 3. It is necessary to require students to carry out automobile disassembling practice for making students better understanding the knowledge of automobile structure. Its term is one week. Auto show exercitation is usually carried out in April each year. It's mostly practice training is to visit Beijing auto show and Shanghai auto show in one week time. Auto market research means requiring students carrying out research to choose vehicle market somewhere in one week time, and form a research report. Automobile marketing plan is making students issue marketing planning case combined with some specific automobile products in two weeks. The planning cases need to reply. Automobile marketing virtual simulation training mainly completed in the laboratory in two weeks. It includes 4S shop virtual simulation training, CRM practice training, SPSS statistical analysis practice training, etc. Automobile marketing internship is mainly carried out in the automobile enterprises and automobile dealers. Its term is one month or two months.

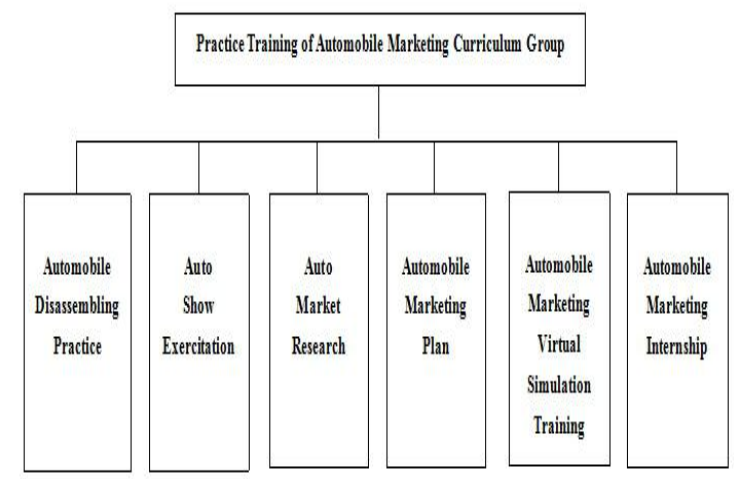

Fig. 3. Practice training of automobile marketing curriculum group

\section{EXPLORATION AND PRACTICE OF AUTOMOBILE MARKETING CURRICULUM GROUP}

The curriculum group of automobile marketing has been exploration and practice for six years since it is completed in
Hubei University of Automotive Technology and achieved obvious effect.

\section{A. Teaching Team of Automobile Marketing Curriculum Has Been Formed}

The teaching team of the curriculum group has been gradually formed in the practice of the curriculum group. Each member not only is responsible for 1 to 2 courses construction of the curriculum group, but also to teach other courses in the curriculum group. Each course has formed course team for 2 to 3 members of curriculum group. This makes each member is more familiar to most of the courses of curriculum group, better grasp emphasis of each course of curriculum group, ensure the validity of the transmission of knowledge and consistency teaching, so as to improve the quality of talent cultivation. In addition, the team often discusses the teaching situation around the construction of automobile marketing curriculum group, and is engaged in the study of the corresponding teaching and scientific. A series of research results has been acquired. Research results feedback teaching and improve the quality of teaching. At present, the core team members of curriculum group are eight, including 5 professors and 3 associate professors. The team has teaching experience, reasonable structure, strong teachers, and rich achievements and is trying to come into an excellent Provincial teaching team.

\section{B. A Number of Series of Characteristics Teaching Materials Have Been Published}

Teaching material is one of the basis of the teaching work, is also the foundation of the curriculum group construction. The team of group formed series of characteristics teaching materials around curriculum group through solidifying and improving teaching achievements in the long-term teaching practice. Curriculum group team has published a number of teaching materials, such as "Automobile Marketing", "Management of Automobile Service Enterprise ", "Automobile Culture", "Foundation and Practice of Automobile Marketing", "Policies and Regulations of Automobile Marketing", "Theory and Case of Auto Parts Trade", "Theory and Practice of Auto Finance", "Auto Parts Marketing", "Essence and Case Analysis of Auto Insurance and Claims". These series of textbooks reflected the idea that knowledge and ability is equally important and theory and combining theory with practice. In addition, these series of textbooks have distinctive features, original content, rich case, and complete system. These series of textbooks play an important supporting role improving the quality of talent training. More importantly, these teaching materials have been choused by many universities. For example, the material of automobile marketing has been choused by Tsinghua University, Shanghai Jiaotong University and other more than eighty colleges and universities. The materials of theory and practice of auto finance has been used by Nanchang University, Changchun Industrial University and other some universities. The material of Essence and Case Analysis of Auto Insurance and Claims has been used by Southwest Jiaotong University, Jilin normal university and other some universities. 


\section{Teaching Resources Has Been Implemented Networked}

Networking of teaching resources is one of important way to implement open teaching and interactive teaching by modern information technology and means. It requires teaching outline, electronic courseware, teaching video, class exercises, extracurricular data, casebook, development frontier and other teaching materials is open to all students on the network, and establishes interactive learning platform to communicate with students. The networking of curriculum group has made students learn from one-way to interactive learning, fixed learning into flexibility, and learning effect was improved. In fact, in the specific teaching practice, the teachers also used other modern teaching means such as We Chat teaching to improve the students' learning initiative.

\section{The Curriculum Group Has Been Utilized in Many Professions}

The curriculum group of automotive marketing is the important content of the construction of the marketing professional, it has been incorporated in the automobile marketing professional talent training scheme, so the knowledge structure and ability requirements of automobile marketing talents is more reasonable and comprehensive. In addition, the curriculum group of automotive marketing has established in other professional such as automobile service engineering, vehicle engineering, international economy and trade, electronic commerce. It makes them engaged in automotive marketing work in the future good foundation.

\section{E. Practice Training of Automobile Marketing Curriculum Group Has Been Solidly Boosted}

Students can fully grasp the performance and the indicators of the automobile through automobile disassembling practice, and it was arranged in the second semester. The students have a preliminary understanding of automobile marketing through auto show exercitation, and it was arranged in the thirdly semester. The teachers often prepare auto show exercitation for three months ahead of schedule, holding mobilization, setting questions, dividing grouping, etc. When it finished, the summary report was convoked. The students have preliminary understood market the conditions of automotive product, preliminary had the ability of auto market analysis through auto market research, and it was arranged in the fourthly semester.
Automobile marketing plan requires students combing the actual conditions of automobile enterprises, and completing in auto enterprise. It was arranged in the fifthly semester. The students master related knowledge and ability of auto sales and learn to use the basic data analysis software through automobile marketing virtual simulation training. It was arranged in the sixthly semester. $\mathrm{T}$ The students enter into state of automobile marketing actual combat through automobile marketing internship. It was arranged in the seventhly semester. The university has signed cooperative agreement with many famous auto companies and dealers for making automobile marketing internship well. The university implements the "double tutors" system for employing enterprise marketing director as intern teachers. So the effect of practice teaching has improved through industry-education integration.

\section{ACKNOWLEDGMENT}

Although the construction of automobile marketing course group has achieved good results by many years of exploration and the practice, there are also some shortcomings, such as the course cohesion of classroom teaching and practice of is not quite close together, research achievements is not rich enough, the teaching method still need to improve, etc. The team of curriculum group will continue to explore and practice, create talent training modes through the construction of curriculum group, improve integrating degree between cultivating talents and social development needs.

\section{REFERENCES}

[1] Chang-pu Ma, "Literature review about the construction of curriculum group research in universities", Youth Literator, vol. 120, pp. 210-211, September 2004(In Chinese).

[2] Hao-yue Dong, "Theory of curriculum group construction in university". Time Education., vol. 59, pp. 28-29, July 2013(In Chinese).

[3] Jing-sen Zhang,Zhen-chuan Du,Jun-jie Zhu, "Several theory and practice problems on construction of curriculum group in the university", Modern Education Science, vol. 161, pp. 64-69, May 2015(In Chinese).

[4] Zhi-xing Cai,Li-yu Liu,Bai-fan Chen, "Construction and experience of quality curriculum group about intelligent science", China University Teaching, vol. 269, pp. 43-45, September 2015(In Chinese).

[5] Qin-wei, "On research of construction of curriculum group in the university", Software Guide, vol. 183, pp. 74-76, August 2015(In Chinese). 